\title{
Party Autonomy in the Choice of Law: Some Insights from Australia
}

\author{
Sagi Peari ${ }^{1}$ (D) Saloni Khanderia ${ }^{2}$
}

Accepted: 18 February 2021 / Published online: 3 March 2021

(c) The Author(s), under exclusive licence to Springer Nature B.V. part of Springer Nature 2021

\begin{abstract}
The party autonomy doctrine represents a very central component of international commerce. According to this doctrine, the parties to an international contract have the freedom to determine the applicable law to govern their dispute. Thus, party autonomy becomes a significant doctrine that affects the nature and effect of crossborder commercial transactions. Furthermore, the doctrine plays a crucial role in addressing the legal challenges caused by the outbreak of the COVID-19 and the growing volume of online commerce that COVID-19 reality has enhanced. By taking Australia as a case study for the party autonomy doctrine, we explore the essential aspects of the doctrine and contemplate on what the future of this doctrine holds for businesses and consumers.
\end{abstract}

Keywords Party autonomy · International contracts · Choice of law · COVID-19 . Frustration · Consumer protection

Sagi Peari

sagi.peari@uwa.edu.au

Saloni Khanderia

skhanderia@jgu.edu.in

1 Business Law Program, University of Western Australia Law School, 35 Stirling Highway, Crawley, WA, Australia

2 Jindal Global Law School, University of Johannesburg, Jindal University, Sonipat, Haryana 131001, India 


\section{Introduction}

The doctrine of party autonomy has increasingly been accepted as the cornerstone in the choice of law rules of several legal systems across the globe. The European Union [EU], ${ }^{1}$ China, ${ }^{2}$ Russia, ${ }^{3}$ Turkey ${ }^{4}$ and Japan $^{5}$ are some common examples. Among the common law systems, the United Kingdom $[\mathrm{UK}],{ }^{6} \mathrm{Canada}^{7}{ }^{7} \mathrm{India}^{8}$ and South Africa ${ }^{9}$ have accepted this doctrine. It permits the parties to an international contract ${ }^{10}$ to choose a law that will govern the rights and liabilities in disputes arising out of their contract. ${ }^{11}$ In doing so, the parties may negotiate and incorporate a "choice of law" clause in a manner that is similar to the other terms and conditions in their contract.

Consider, for example, that two contracting parties from New South Wales [NSW] and Singapore have concluded a credit insurance contract. The parties may agree on the application of English law to govern their agreement for several reasons. English law would serve as a "tie breaker" between NSW's and Singapore's rules by being neutral. Furthermore, the UK credit insurance law is well-developed and relatively widespread in international commerce which even enhances the apparent legitimacy of the parties' choice. ${ }^{12}$ The party autonomy doctrine seems to be convenient and relatively straightforward common sense: the contracting parties should have the autonomy to determine the applicable law.

The significance of party autonomy is crucial at the time of COVID-19's unprecedented challenges. The ramifications of epidemics, such as COVID-19 on international commerce, are manifold. The outbreak has resulted in significant delays or even delivery cancellations in the performance of inter alia many contracts of products and services. The implementation of governmental restrictions on the mobility of people, social distancing, limitations and the closure of many businesses has led to the inability of businesses and people to perform their contractual obligations.

\footnotetext{
1 Article 3 (1), Regulation (EC) No 593/2008 of the European Parliament and the Council on the Law Applicable to Contractual Obligations (2008).

2 Article 3, The Law of the People's Republic of China on the Laws Applicable to Foreign-Related Civil Relations (2010).

3 Article 1210, Civil Code of the Russian Federation (2015).

4 Article 24, Turkish Code on Private International Law and International Civil Procedure (2007).

5 Article 7, Japanese Act on the General Rules on the Application of Laws (2007).

6 Fawcett \& Carruthers (2017: 683-696), Enka Insaat ve Sanayi AS v OOO "Insurance Company Chubb [2020] 1 WLR 4117, 4126-4127.

7 Pitel \& Rafferty (2016: 285-304).

8 National Thermal Power Corporation v Singer Corporation, 1992 (3) SCC 551 (Supreme Court of India), Khanderia (2018: 1, 8); Khanderia (2020; 5).

9 Creutzburg v Commercial Bank of Namibia Ltd [2006] 4 All SA 327, 330; Representative of Lloyds v Classic Sailing Adventures (Pty) Ltd, 2010 (5) SA 90 (SCA), Niekerk \& Schulze (2016: 60-62).

10 Rühl (2014: 338-339), Mortesen et al (2019: 444).

11 Symeonides (2019), Mills (2018), Coyle (2020).

12 Cf Akai Pty Ltd v People's Insurance Co Ltd (1996) 188 CLR 418.
} 
Various legal systems have different visions on how they handle uncontrollable, unforeseen, supervening events which hinder the performance of the contract. ${ }^{13}$ Certain governments such as those of Russia ${ }^{14}$ and China ${ }^{15}$ have provided force majeure certificates to their commercial actors as a proof of the unforeseen circumstances in their jurisdictions to certify that performance of the contracts concluded by them would not be possible due to the same. How will the courts resolve the issues of contractual performance? The answer differs; and in the case of international contracts, would depend on the law that will govern the contract. Since the vast majority of international contracts include a choice of law clause, ${ }^{16}$ the status and scope of the doctrine of party autonomy become indispensable.

Party autonomy principle becomes even more relevant in COVID-19 reality which has dramatically enhanced the internet-based commerce. ${ }^{17}$ This immediately raises the question of the applicable law in the online mediums of commerce. Both the parties may have incorporated the choice of law clause in the standard terms of their contract which appears at the back. ${ }^{18}$ The predicament of conflicting standard terms is known as the battle of forms, and it becomes crucial to ascertain which parties' choice of law will prevail. ${ }^{19}$ The rules that each jurisdiction adopts to resolve such predicaments may vary. ${ }^{20}$ Would these online choices of law clauses be valid? Even if the answer is "yes", what should the scope of party autonomy be to determine the applicable law and what are the potential (if any) limitations? How the ordinary rules of the party autonomy principle apply to online modes of contracting?

Furthermore, the decision of the Federal Court of Australia in Valve Corporation $^{21}$ has provided a fascinating case study to explore the relationship between the doctrine of party autonomy and such notions as mandatory rules and the internetenhanced environment of COVID-19. Involving a factual situation of contracts signed between multi-billion online US company and hundreds of thousands of Australian consumers, ${ }^{22}$ this decision represents a landmark step in the future direction of party autonomy in Australia.

\footnotetext{
13 Hondius \& Grigoleit (2011), Notage (2007).

14 Pannebakker, "Force majeure certificates' issued by the Russian Chamber of Commerce and Industry" 17 April 2020, online: conflictoflaws.net.

15 Tang, "Coronavirus, force majeure certificate and private international law" 1 March 2020, online: conflictoflaws.net.

16 The empirical evidence from the field of international arbitration suggest that more than $85 \%$ of contracts include a choice-of-law clause, see Hayward (2017: 21-23).

17 See eg online: https://www.digitalcommerce360.com/2020/03/19/coronavirus-will-boost-ecommercein-the-long-run-but-brings-new-risks/ (mentions that COVID-19 will "...boost ecommerce in the long run, but brings new risks").

18 Graziano (2013:87); Graziano (2017); Hague Conference on Private International Law, "Commentary on the Hague Principles on Choice of Law in International Contracts" (approved 15 March 2015), online: www.hcch. net/en/instruments/conventions/full-text/?cid=135, Khanderia (2019: 11-13).

19 Ibid.

20 Graziano (2013: 87); Khanderia (2019: 3-13).

21 [2017] FCAFC 224.

22 See the 'Age of Mandatory Rules' section below.
} 
This is indeed the theme of this paper. We aim to make some observations on the status of the party autonomy in Australian jurisprudence and to make suggestions about its role in the future. The paper is structured as follows. Part I presents nine key questions that seem to be immanent to party autonomy doctrine and contemplates on the possible answers of Australian jurisprudence. In light of the significance of Valve Corporation, Part II exclusively focuses on this decision and its role for the future of party autonomy in Australia. Part III provides the concluding remarks.

\section{Party Autonomy in the Choice of Law and COVID-19: the Nine Questions}

Question 1: What is the relationship between the doctrine of party autonomy and the traditional classification of the field?

Traditionally, private international law cases have been distinguished from purely domestic cases due to the presence of a certain "foreign" element within the factual basis of a claim. ${ }^{23}$ A contract between two Victoria residents signed in Melbourne which addresses the delivery of goods in Melbourne is an example of a purely domestic contract. The principles of private international law (and subsequently the choice of law) would not apply to such types of contracts. This, indeed, seems to be the position of several choice of law provisions across jurisdictions which eliminate, or at least limit, the application of the party autonomy doctrine in purely domestic cases. $^{24}$

The question is whether the doctrine of party autonomy should be affected by this traditional classification of the field. Consider two contracting parties from the Australian state of Victoria who sign a contract in Melbourne (i.e. in Victoria) that deals with the delivery of goods in Victoria. Can these parties choose a non-Victorian law, say French law, to govern their future dispute? It does not seem that Australian jurisprudence has directly addressed this question. However, some comments on this matter can be noticed. Scholarly writings suggest that the question of applicable law in contracts refers to a specific kind of international or multi-state contracts. ${ }^{25}$ Online contracts' frequently feature foreign elements' ${ }^{26}$ From this perspective, it would appear that at least implicitly, Australian jurisprudence continues to adhere to the classical definition of the field.

Why should the presence of a single "foreign element" affect the parties' ability to set their rights and duties? The requirement of a single foreign element seems to be a bit anachronistic in a world where goods are manufactured in different places. Furthermore, the internet seems to represent an inherently cross-border, a-territorial

\footnotetext{
23 Hill \& Shúilleabháin (2016: 1), Cheshire \& North (2017: 3).

24 Article 1, Hague Principles on Choice of Law in International Commercial Contracts (2015), Article

1 (2) Commission Regulation 864/2007, on the Law Applicable to Non-Contractual Obligations (Rome II), 2007 OJ (L 199) 40 (EC).

25 Davies et al (2020: 472).

26 Mortesen et al (2019: 439-467).
} 
phenomenon what challenges the traditional classification of the field. ${ }^{27}$ It can be argued that the internet presents a built-in foreign element. Accordingly, it can be argued that all online cases (even in the case of a contract between two Victoria residents concerning delivery of goods in Victoria, as in the example mentioned above) should be classified as private international law cases. Arguably, it should always be open to the parties to exercise their autonomy in the case of internet communications.

The position of Australian jurisprudence seems to be undesirable. The nature of contemporary commerce and business appears to be very much transnational. Led by the COVID-19 crisis, the era of internet commerce will lead to a situation when the inherently transnational phenomenon of online business becomes the almost exclusive medium of transactions. In these circumstances, it seems to be undesirable conceptually, ${ }^{28}$ and especially practically to adhere to the formal sharp traditional distinction between purely domestic and multi-state contracts. The foreign element can mostly be found everywhere.

Question 2: What happens when the parties have chosen a law which has no connection with their transaction?

One of the perplexing differences between the American, on the one hand, and European jurisprudence, on the other hand, is the question of whether the law requires the parties to demonstrate some connection between them, the transaction and the applicable law. While US law explicitly invokes this sort of limitation on the parties' choice, ${ }^{29}$ European legislation does not. ${ }^{30}$

The jurisprudence on the point of a required (if any) connection to the chosen law under the party autonomy principle is somewhat mixed in Australia. On the one hand, older cases seem to support the traditional American approach, which requires demonstrating a meaningful connection with the chosen law. ${ }^{31}$ On the other hand, more recent cases vividly deny the need for such a connection. ${ }^{32}$ Thus, as we have seen, ${ }^{33}$ the Australian High Court has acknowledged and confirmed the legitimacy of the parties' choice in Akai. The choice of English law, in that case, served as a tiebreaker and reflected an implication of a "relatively certain and well-developed"34 legal framework for deciding the rights and duties of the parties under credit insurance contract signed in this case.

Perhaps, the future of Australian jurisprudence should continue to deny the relevancy of a meaningful connection of the parties or their transaction with their choice

\footnotetext{
27 On the a-geographical nature of the internet, see Svantesson (2016: 1, 56, 82), Wang (2019: 3, 87).

28 Peari (2018: 79-125).

$29 \$ 187$ (2), Restatement (Second) of Conflict of Laws (1988); Zhang (2015).

30 Briggs (2014: 543-544).

31 Kay's Leasing Corp v Fletcher (1964) 64 SR (NSW) 195, 205; Queensland Estates Pty Ltd v Collas [1971] Qd R 75, 80-1.

32 Huntingdale Village Ltd v Corrs Chambers Westgarth (2018) 128 ACSR 168 AT 209; Ship 'Sam Hawk' v Reiter Petroleum Inc (2016) 246 FCR 337, 400 (honouring the parties' choice of a law unrelated to them).

33 See 'Question 1' above.

34 Mortesen et al (2019: 445- 446).
} 
of law under the party autonomy doctrine. ${ }^{35}$ This interpretation will assist the Australian courts to continue to adhere to international standards - where most legal systems allow the choice of any neutral, foreign law.

Question 3: Will the Australian courts permit the parties to incorporate by reference the provisions of a non-state law?

One of the most perplexing questions that preoccupy the contemporary private international law scholarship tackles the hypothetical possibility of the parties to choose a framework which does not represent an official law of any of the existing states. ${ }^{36}$ Some religious laws by their nature aim to cover almost every aspect of human life. Could non-state provisions such as the Islamic Sharia and the Jewish Talmudic law serve as a potential choice of the parties? Or must the incorporate by reference, the provisions of non-binding legal principles such as the Principles of European Contract Law ${ }^{37}$ or the UNIDROIT Principles on International Commercial Contracts $^{38}$ into the terms of their contract instead of selecting it as the applicable law? Subject to certain exceptions, ${ }^{39}$ the general tendency of the choice of the law jurisprudence is to prohibit the choice of soft law or incorporating by reference, the provisions of the same in the parties' contracts. ${ }^{40}$

There are some legal systems such as Mexico and Venezuela which permit the parties to choose general principles of law such as the PICC or PECL. ${ }^{41}$ The Hague Principles $^{42}$ which are in the form of non-binding recommendations advocate the extension of the doctrine of party autonomy to the choice of soft law. ${ }^{43}$ Some others, such as the $\mathrm{UK}^{44}$ and India ${ }^{45}$ do not permit the selection of such non-binding legal principles but allow the parties to incorporate their provisions by reference. Without formally adopting the non-state law through the choice of law clause, the non-state law could therefore de-facto govern the contract. Should the law tolerate a situation where a non-state law enters the picture clandestinely?

Australian jurisprudence appears to follow India and the UK on this matter. Thus, on several occasions, the Australian courts have indicated that it is open to the parties incorporating substantive provisions of a non-state law in their contract, such as

\footnotetext{
35 For a related point on the rejection of the meaningful connection limitation, see Davies et al (2020: 477).

36 Boele-Woelki (2010: 401-419); Symeonides (2010: 539-540).

37 Principles of European Contract Law (Kluwer International Law, 1999).

38 UNIDROIT, UNIDROIT Principles on International Commercial Contracts, 2016, online: www.unidr oit.org/english/principles/contracts/principles2016/principles2016-e.pdf

39 Article 3, Hague Principles on Choice of Law in International Commercial Contracts (2015).

40 Cheshire \& North (2017: 713-715). To note, that even in the area of international arbitration, where the possibility of incorporating the non-state provisions exists, the empirical data suggest that the parties invoke this possibility in exceptionally rare cases. Hayward (2017: 208).

41 Article 9, Inter-American Convention on the Law Applicable to International Contracts, signed at Mexico, March 17, 1994.

42 Neels (2015: 774-775).

43 Articles 2 \& 3, Hague Principles on Choice of Law in International Commercial Contracts (2015).

44 Halpern v Halpern [2007] EWCA Civ 291, [2007] 2 Lloyd's Rep 56.

45 See the decision of the Telecom Dispute Settlement and Appellate Tribunal (TDSAT), New Delhi in Kumarina Investment Ltd. v Digital Media Convergence Ltd \& Anr, 2010 TDSAT 73 [27].
} 
religious law. ${ }^{46}$ While the courts see such incorporations as a legitimate practice, it is not the case with choice of law clauses in favour of non-binding rules which do not represent an official law of one of the states. The possibility of choosing a nonState law does not seem to exist under Australian law. ${ }^{47}$

This sharp distinction between the potential incorporation of a non-state law within the choice of law clauses and the selection of the very same law to regulate the entire contract seems to be unfortunate and a bit formalistic. What seems to matter on the point of non-state law is the question of the comprehensiveness and predictability of a given provision. A review of the choice of law literature on this point suggests that the incorporation of non-state rules under the party autonomy doctrine should be limited to those frameworks which are predictable enough and comprehensive enough that they would operate similarly to ordinary legislative provisions. As one scholar put it "[t]he ultimate test ought to be to ask whether the system of rules chosen is specific and clear enough for a court to be able to apply it to the issues which arise between the parties."48

These requirements of predictability and comprehensiveness would probably exclude the application of the amorphous merchant law (lex mercatoria) ${ }^{49}$ as a potential candidate for a choice of law clause. The reasonably comprehensive provisions of the PICC should have been accepted. In a similar vein, it should be possible to incorporate several comprehensive and fairly predictable frameworks of religious laws which through the centuries have created a body of law which has been compared with common law in their comprehensiveness and sophistication. ${ }^{50}$

Question 4: What is the impact of online modes of communications on the party autonomy principle?

Scholars have acknowledged the centrality of online modes of contracting as a 'necessary aspect of modern life'. ${ }^{51}$ However, there are some concerns about the specific nature of online contracts where the parties' signature requires a mouse click on "I agree", and usually has been presented to consumers on a take it or leave it basis. ${ }^{52}$ Research demonstrates that online modes of communication magnify issues of transparency of the dealing and raise the question of the information available to the parties. ${ }^{53}$ It has also been acknowledged that online forms of contracting tend to incorporate choice of law clauses which favour a more powerful party under the contract. ${ }^{54}$

\footnotetext{
${ }^{46}$ Engel v Adelaide Hebrew Congregation Inc (2007) 98 SASR 402, 409; Re South Head \& District Synagogue (Sydney) (2017) NSWSC 823, [29].

47 Davies et al (2020: 468). Mortesen et al. seems to be less determinative on this point, by commenting that "[t]he current Australian law would probably prohibit such a choice". Mortesen et al (2019: 439, $n$ $1)$.

${ }^{48}$ Briggs (2008: 388), Basedow (2013: 171-173).

${ }^{49}$ Michaels (2014: 50).

${ }^{50}$ For further discussion of this point, see Geva \& Peari (2021: 156-159).

${ }^{51}$ Davies et al (2020: 472).

52 Ibid, p. 470.

${ }^{53}$ Garnett (2017: 586).

${ }^{54}$ Mortesen et al (2019: 463).
} 
Enhanced by the COVID 19's outbreak, the era of the internet should have changed the way we see the principle of party autonomy. The choice of law clauses appears in almost every contract. They invariably find a place in the standard terms of the contract. ${ }^{55}$ Seldom do the contracting parties know each other or read each other's standard terms in internet-based communications - especially when they are concluding an international agreement. ${ }^{56}$ Therefore, they should be subject to stricter rules. The parties are likely to begin the performance of their obligations based on what they interpret to be the terms of the contract. ${ }^{57}$ If a dispute arises, the adjudicator would need to refer to the parties' choice of governing law. In such a circumstance, the conflict has the potential to become extremely complicated for two reasons. Firstly, because the court or arbitrator would have to ascertain if the agreement is valid due to the existence of contradictory terms. Secondly, if the agreement is valid, then which parties' choice of law will govern the dispute if different laws have been designated ? $^{58}$

The law of contract of every country, including Australia, stipulates a mechanism to resolve an ambiguity arising from conflicting terms in the parties' agreement. However, referring to the lex fori would be present an "imperfect solution" 59 when extended to choice of law clauses for the simple reason that traditional solutions are directed at domestic as opposed to international agreements. Disputes arising from transnational contracts can be resolved by applying the substantive principles of any country when it has been identified as the governing law by the adjudicating authority according to its private international law rules. ${ }^{60}$

Australian jurisprudence has not delineated special choice of law rules to online modes of contracting. Presently, such agreements are governed by the same set of rules applicable to ordinary contracts. ${ }^{61}$ Case law demonstrates the caution that Australian courts exercise in invalidating contractual terms and conditions, including in the context of online contracting. ${ }^{62}$ This view appears to consider the significance of the values of predictability and efficiency of contractual arrangements generally and the needs of online business, specifically.

Australian jurisprudence would need to designate a significant effort in the years to come in tackling the nature of the choice of law rules applicable to online contracts. In the meanwhile, it is suggested that Australian courts consider employing the recommendation of the Hague Principles to interpret and develop the law while resolving predicaments that arise from the conflicting choice of law clauses. ${ }^{63}$

\footnotetext{
55 Graziano (2013: 72).

56 For comments in this direction see Benoliel \& Becher (2019).

57 Khanderia (2019: 2).

58 Graziano (2013: 81).

59 Ibid, pp 82-83.

60 Ibid, p 80.

61 Turner (2019: 51-69).

62 Gonzalez v Agoda Pty Ltd (2017) NSWSC 1133. See also Benoliel \& Becher (2019: 56) (outline the present anomaly within the US context where the courts continue validating online terms and conditions, despite the spiking criticism of scholars).

63 Article 6(1) (b), Hague Principles on Choice of Law in International Commercial Contracts (2015).
} 
Accordingly, the court may examine the terms of the contract to ascertain whether the parties have chosen laws of different countries which adopt a) a similar or b) a different mechanism to resolve the battle of forms. ${ }^{64}$

To illustrate, suppose the parties have chosen Indian and English law, respectively. India and the UK adopt the last-shot method - where the contract is concluded on the terms of the party who made the counter-offer once it has been accepted. ${ }^{65}$ In such a case, referring to the Hague Principles, an Australian court would apply the last-shot method to decide which party's choice of law will prevail because India and the UK adopt the same mechanism to resolve the predicament of the battle of forms. ${ }^{66}$ If, however, the parties chose the law of the UK and the Netherlands, respectively, then an Australian court would disregard the choice of law altogether and identify the same according to its private international law. ${ }^{67}$ This is because while the UK adopts the last-shot method, the Netherlands applies the first-shot rule - according to which the terms of the offer (and not the counter-offer) will prevail. ${ }^{68}$ Both of these rules differ. Hence, an Australian court would disregard them and identify the applicable law as if the parties have not made any choice. ${ }^{69}$

The growing number of these contracts in a COVID-19 environment only intensifies the need to adopt a predictable solution. While Australian law has now drawn a sharp line between consumer and business contracts (as we discuss in details in Part 2 ), it is clear that it also requires a corresponding comprehensive examination of agreements which have been concluded online.

Question 5: Does the parties' choice of law refer to specific nuances of the contract?

Traditionally, the jurisprudence on private international law has been equivocal on whether the governing law will extend to disputes involving specific areas of the contract concerning its formation-such as the offer, acceptance, the element of consideration, the question of the parties' capacity, the question of the formal (if any) requirements of the contract and the issues of legality. These have been coined as "particular issues" 70 of the agreement. On the one hand, a review of some jurisdictions suggests that some have adopted a modified set of rules related to these "particular issues". ${ }^{71}$ On the other hand, due to the uncertainty and the disagreements amongst the scholars, some legal frameworks have simply excluded the "particular issues" from their scope. ${ }^{72}$

\footnotetext{
64 Ibid. Graziano (2013: 87-89), Khanderia (2019: 11-13).

65 Khanderia (2019: 3-4, 13-17), Rühl (2003: 190-191).

66 Article 6 (1) (b), Hague Principles on Choice of Law in International Commercial Contracts (2015).

67 Ibid.

68 Khanderia (2019: 5).

69 Article 6 (1) (b), Hague Principles on Choice of Law in International Commercial Contracts (2015).

70 Cheshire \& North (2019: 751).

$71 \S \S 198-199$, Restatement (Second) of Conflict of Laws (1988), Pitel \& Rafferty (2016: 296-297).

72 Article (2) (a), Regulation (EC) No 593/2008 of the European Parliament and the Council on the Law Applicable to Contractual Obligations (2008) (generally excluding the questions of capacity from the scope of the Regulation).
} 
The legal position is, therefore, not clear on this point. ${ }^{73}$ Alongside the worldwide adoption of the doctrine of party autonomy, there is a question whether it can be easily extended to the "particular issues" which are governed by the law of contract. One can argue that certain areas of law (such as capacity and questions that deal with the genuineness of the parties' consent under the contract) creates a chickenegg problem for the application of this principle. ${ }^{74}$ How would it be possible for the parties to justify their autonomy if their free will has not yet been determined? How would it be possible to apply the party autonomy principle to questions that tackle the very autonomy of the parties?

A review of judicial dicta in Australia demonstrates that the practice of the courts has not been uniform. In some cases, the courts have referred to the chosen law to resolve disputes on such matters. ${ }^{75}$ In other instances, the courts have demonstrated the preference of referring to the law of the forum (lex fori) to resolve issues on the formation of the contract, offer and acceptance, and the genuineness of the parties' consent. ${ }^{76}$ Some of the conflict of laws textbooks in Australia have included a specific discussion of "particular issues" of contract law. ${ }^{77}$ In the past, the Law Reform Commission recommended extending the application of the parties' choice to determine "particular issues" of the contract, such as contractual capacity and the formation of contracts. ${ }^{78}$

Perhaps, the consideration of coherency and consistency would support the application of a unified framework of choice-of-law rules to all aspects of contract law. The doctrine of party autonomy will play a leading role in this framework. There is a way to incorporate the chicken-egg problem within the conceptual foundations of the party autonomy. ${ }^{79}$

Question 6: When the parties explicitly name the applicable law, do they refer to the domestic law of a given system, or do they intend to include conflict of law provisions of the country as well?

Another interesting question of the doctrine of party autonomy relates to the scope of the parties' choice. To illustrate, a company incorporated in Victoria, Australia concludes a contract to sell certain goods to a Chinese company. The parties agree on the application of French law to govern the disputes arising from the contract. Does this imply that the parties agreed to submit themselves strictly to French law, or did they intend to submit to the French legal system as a whole? In the latter case, this would also mean submission to the principles of French private international law which could lead to the law of another country other than France. The conflict of law rules of France is stipulated in the Rome I Regulation which are

\footnotetext{
73 Pitel \& Rafferty (2016: 296-297).

74 Briggs (1990: 200), Lorenzen (1917: 18).

75 Mortesen et al (2019: 455) ("The trend over the twentieth century was that the concept of the proper law progressively extended its role, and replaced other connecting factors for identifying the law of the cause in specific issues relating to a multi-state contract").

76 Ibid, pp 455-457.

77 Cheshire \& North (2019: 751).

78 Australian Law Reform Commission, Choice of Law No 58, AGPS, Canberra, 1992, [8.59].

79 Peari (2018: 90-125).
} 
applicable to determine the governing law in a dispute arising from a contractual obligation. The Rome I Regulation will apply the principle of characteristic performance, according to which, the law of the seller will govern the dispute. ${ }^{80}$ If the parties' choice of law includes to conflict of law principles of France, then the law of Victoria will apply instead of French law.

The potential reference to the entire rules of a foreign system and the application of its choice of law rules has been coined in the literature as the doctrine of renvoi. ${ }^{81}$ While the conceptual debate around this doctrine is fascinating, it has been almost universally rejected. ${ }^{82}$ The question remains whether renvoi has any future in Australia, specifically in the context of the courts' interpretation of the doctrine of party autonomy.

Australia does not express any hostility towards the application of renvoi. The High Court of Australia in Neilson v Overseas Projects ${ }^{83}$ has accepted the validity of this doctrine in the area of tort law. ${ }^{84}$ Accordingly, it could reasonably be stated that the possibility of incorporating the doctrine in the field of Australian private international law of contract is "an open question". ${ }^{85}$ At the same time, one can argue that renvoi should not be a part of the Australian choice of law rules applicable to contracts. Its use in Neilson has been sharply criticised as a disguise or a manipulative technique to avoid the harsh result that would have inevitably occurred had Chinese law been applied in this case. In other words, the court applied renvoi in Neilson not due to its doctrinal soundness, but as a means to prevent the application of Chinese law of negligence. ${ }^{86}$ The extension of the doctrine beyond tort law is, therefore, doubtful.

Beyond everything, it seems to be questionable whether renvoi confirms the underlying rationale of party autonomy. By choosing a law of a country, the parties do not choose the entire private international law of that system to apply. ${ }^{87}$

Question 7: when the parties do not expressly agree on the identity of the applicable law, can their 'inferred' or 'implied' choice serve as a subsidiary doctrine of the party autonomy?

In the English decision of Amin Rasheed Shipping Corp v Kuwait Insurance Co, ${ }^{88}$ the court adopted the majority view that certain aspects of the contract may infer the choice of the parties' as regards the law that should govern the agreement in the

\footnotetext{
80 Article 4 (1), Regulation (EC) No 593/2008 of the European Parliament and the Council on the Law Applicable to Contractual Obligations (2008).

81 Clarkson \& Hill (2016: 33-41).

82 Article 8, Hague Principles on Choice of Law in International Commercial Contracts (2015), Article 20, Regulation (EC) No 593/2008 of the European Parliament and the Council on the Law Applicable to Contractual Obligations (2008), Amin Rasheed Shipping Corporation v Kuwait Insurance Co [1984] AC $50,61-62$.

83 (2005) 223 CLR 331; [2005] HCA 54.

84 Davies et al (2020: 496-510).

85 Ibid, p 466, Mortesen et al (2019: 441-442).

86 Peari (2019: 105, n 144).

87 For the criticism of the Renvoi doctrine from this standpoint, see Mortesen et al (2019: 441), Peari (2018: 105-106). See also Proactive Building Solutions v Keck [2013] NSWSC 1500 at paras 27- 30.

88 AC (1984) 50.
} 
absence of an express indication to the same. This principle is commonly referred to as the tacit or implied choice of the parties. The factors that the court could refer to include: the language of the contract, its specific form and an agreement conferring jurisdiction on a court (popularly referred to as a choice of court or forum-selection clause). ${ }^{89}$ Several jurisdictions across the globe refer to the tacit choice of the parties to identify the governing law. ${ }^{90}$

The High Court of Australia in $A k a i^{91}$ made it clear that Australian jurisprudence follows the decision of the English court in Amin Rasheed Shipping. ${ }^{92}$ Accordingly, the implied, inferred, or tacit choice of the parties can be regarded as subsidiary to the doctrine of party autonomy to shed light on the parties' choice of the applicable law. ${ }^{93}$ Australian courts would accordingly consider factors like the language of the contract, its form, and the forum-selection clause as relevant to identify the applicable law. ${ }^{94}$

One can argue, however, that this position of the Australian jurisprudence should be reconsidered. One can doubt the ability of such factors as the language, form, and even jurisdiction clause to be directly linked to express choice under the party autonomy doctrine. ${ }^{95}$ A preferable approach when the parties have not expressly selected the governing law has been suggested by Lord Wilberforce in the Amin Rasheed Shipping, who preferred the application of the traditional common law' closest and most real connection' test. ${ }^{96}$ The courts would assess the parties' interaction as a whole and to apply the law of that country which has the closest connection to the parties and their transaction. ${ }^{97}$ A close examination of the indicative factors that will be relevant to identify the inferred choice demonstrate that these are identical to the criterion that will be considered for the "closest and most real connection" test. ${ }^{98}$

Question 8: What is the status of public policy and 'good faith' limitations?

Even without the inherent challenges of internet modes of contracting, the status of the traditional limitations to party autonomy stipulated in the English dictum of Vita Food Products $v$ Unus Shipping Co ${ }^{99}$ remains unclear. In this decision, Lord

\footnotetext{
${ }^{89}$ Cheshire \& North (2017: 716-722). For a recent decision of the UK Supreme Court on the significance of the parties' choice of arbitration location for the purposes of the question of applicable law to govern the arbitration, see Enka Insaat ve Sanayi AS v OOO "Insurance Company Chubb [2020] 1 WLR 4117, 4167-4168.

90 See for instance, Article 24, Turkish Code on Private International Law and International Civil Procedure, 2007; Article 1210, Civil Code of Russian Federation 2015.

91 Akai Pty Ltd v People's Insurance Co Ltd (1996) 188 CLR 418.

92 AC (1984) 50.

93 Mortesen et al (2019: 447-448).

94 Akai Pty Ltd v People’s Insurance Co Ltd (1996) 188 CLR 418, 431-432.

95 Geva \& Peari (2021: 162-170).

96 AC (1984) 50.

97 See eg Clarkson \& Hill (2016: 12) ("The examples demonstrate the prevailing approach adopted by English law to the issue of choice of law: in the absence of party choice, the parties can be deemed reasonably to expect their relationships and transactions to be governed by the law with which those relationships and transactions are most closely connected".

98 For a further discussion on this notion, see Geva \& Peari (2021: 162-170), Khanderia (2021).

99 [1939] AC 277.
} 
Wright clarified that party autonomy in the choice of law would be disregarded if the court found that it was not "bona fide or contravened the public policy". ${ }^{100}$ Academic writings have expressed that the choice of law clause will be considered as not being "bona fide" if the parties did not act in good faith. ${ }^{101}$

The Australian courts have treated the traditional limitations that were stipulated in Vita Food per Lord Wright ${ }^{102}$ with caution. As indicated above, bona fide has been construed as good faith. ${ }^{103}$ However, its interpretation is subjective. ${ }^{104}$ Consequently, Australian scholars have regarded this limitation as "vague", 105 and have suggested that it "should no longer be regarded as good law". ${ }^{106}$ Albeit being more popular in the courts, the "public policy" limitation has been invoked in exceptional circumstances, ${ }^{107}$ such as situations when a foreign law provision violates "some deep-rooted tradition of the common weal". ${ }^{108}$

Perhaps, the future of the traditional limits on party autonomy depends to a much higher degree on the status and development of other restrictions. The rise of the substantive limitations (see Question 9 below) and the notion of mandatory rules (see Part 2 below) could provide guidance on this matter.

Question 9: In what way do the rise of the substantive doctrines limit the party autonomy in the choice of law?

Apart from the traditional limitations on the party autonomy doctrine, and the growing significance of the overriding mandatory rules (Part 2 below), there is a clear call amongst scholars to subject choice of law analysis to several substantive doctrines. The point is that choice of law clauses should be tested against such notions as "international human rights", 109 "international due process", 110 "substantive unfairness", ${ }^{111}$ and the "ethical moment". ${ }^{112}$ Appearing under different names, titles and labels, these substantive doctrines can limit the possible operation of the parties' freedom to choose a governing law.

Australian jurisprudence has not yet been receptive to the incorporation of various substantive doctrines. As indicated above, the limitations to party autonomy in the choice of law in Australia remains unclear for several reasons. These are due to a) the absence of consistency in the courts' approach towards accepting the choice of foreign law with a lack of meaningful connection; b) the ambiguous nature of "bona

\footnotetext{
100 Ibid, 290.

101 Kincaid (1993: 112).

102 [1939] AC 277, 290.

103 Kincaid (1993: 112).

104 Ibid.

105 Davies et al (2020: 477).

106 Mortesen et al (2019: 445).

107 Ibid, 447.

108 John Pfeiffer Pty Limited v Rogerson (2000) 203 CLR 503, 541.

109 Briggs (2019: 232), Michaels (2008:131).

110 Kotuby \& Sobota (2017: 200).

111 Rühl (2018).

112 Knop el al (2012: 641) (mentioning the significance of "ethical", substantive quality assessment of the involved provisions within the formal structure of choice of law process).
} 
fide", c) the limited parameters within which the courts give effect to public policy, and d) the discrepancies in the interpretation of the Valve Corporation dictum (Part 2 below). These factors all suggest that Australian jurisprudence should take a comprehensive approach to the party autonomy doctrine. This approach should take into consideration a broad spectrum of aspects of the matter, including the notion of international human rights and other substantive doctrines.

\section{The Age of Mandatory Rules in Australia}

Question 10: What is the relation between the party autonomy doctrine and the mandatory rules of the forum?

Mandatory rules operate as an exception to the parties' freedom to choose the applicable law. In essence, their application would allow the forum to bypass certain areas of rules which would apply because of the parties' choice of law and to apply its law (the lex fori). ${ }^{113}$ Scholarly writings articulate that a provision would be construed as an overriding mandatory norm if it is intended to protect particular fundamental interests of the forum-State. ${ }^{114}$ An overriding mandatory rule is, thus, meant to perform certain special functions to protect the public policy of the lex fori; and is, therefore, a subset of the latter. ${ }^{115}$ Consumer, insurance and employment contracts are some representative examples where overriding mandatory rules may apply regardless of the parties' choice of another foreign law. ${ }^{116}$

Tracing their somewhat troubling origins to the writings of the foundational father of the field- Friedrich Carl von Savigny, ${ }^{117}$ courts will disregard the parties' choice of law to give effect to an overriding mandatory norm which is intended to safeguard public interests such as the political, social and economic organisation of the forum. ${ }^{118}$ Thus, the governments of Italy ${ }^{119}$ and Greece ${ }^{120}$ have undertaken specific measures to protect the interests of transport, accommodation and the tourism industry. Contracts of transportation, accommodation and package travel have been designated as overriding mandatory provisions to combat issues of non-performance of contracts due to the COVID-19 pandemic. Obligations arising from such agreements will be regarded as impossible to perform by being an overriding mandatory norm under the Italian and Greek laws, regardless of the law chosen by the parties.

\footnotetext{
113 Briggs (2008: 382), Article 11, Hague Principles on Choice of Law in International Commercial Contracts (2015).

114 Davies et al. (1999:199-207).

115 Ibid.

116 Borchers (2008: 1657-1659), Basedow (2013: 189-193, 343-375).

117 Peari (2018: 205-219).

118 Article 9, Regulation (EC) No 593/2008 of the European Parliament and the Council on the Law Applicable to Contractual Obligations (2008), Bochove (2014).

119 Article 1463, Italian Civil Code, 1942, Piovesani (2020).

120 Articles 61, 65, 70 and 71 of Acts of Legislative Content of 13 April 2020, Anthimos (2020).
} 
In comparison, overriding mandatory norms have not easily been invoked by the courts in the US ${ }^{121}$ and Canada ${ }^{122}$ to disregard the parties' choice of law.

As we have mentioned, ${ }^{123}$ the Federal Court of Australia's dicta in Valve Corporation is a monumental decision in the Australian landscape on the point of the relationship between the party autonomy doctrine and the mandatory rules. The impact of the decision should start with an exposition of the basic features of the Australian Consumer Law (ACL). ${ }^{124}$ Legislated in 2010, ${ }^{125}$ ACL provides a broad definition of a "consumer" according to which, the purchase of a product or a service should be i) for a personal (rather than commercial) use, ${ }^{126}$ or ii) under the nominal threshold of $\$ 40,000 .{ }^{127}$ Such agreements would be considered "consumer" contracts. ${ }^{128}$

In 2016, ACL further extended the application of some of its provisions to "small business" contracts which are ascertained according to the value of an agreement (up to $\$ 300,000$ ) and the number of employees (up to 20 employees) that a given business employs. ${ }^{129}$ What stands at the basis of the sharp distinction between business to consumers [B2C] communications is the insight that consumers (as well as small businesses) are situated in a much weaker position in comparison to corporations. At the same time, the rationale is that business to business [B2B] communications involve sophisticated commercial actors that do not require special protection from the law. ${ }^{130}$

In terms of its provisions, ACL affects in a reasonably dramatic way into the traditional common law foundations of Australian contract law. For our purposes, the role of two central ACL's doctrines of "unfair contract terms", 131 and "consumer guarantees" 132 should be discussed. Under this former, Australian consumer law has the power to invalidate a term in a given contract if the adjudicative tribunal considers it to be an "unfair contract" term. The legislation provides a two-fold test for defining the "unfair contract" term. ${ }^{133}$ First, the term should be a part of a "standard contract" which ACL defines as a "take it or leave it" contract. ${ }^{134}$ Second, the given term needs to be unfair in the sense that it applies in a one-sided manner and supports the interests of only one party of the bargain. ${ }^{135}$ The subsequent case law has precisely focused on this one-sidedness aspect of the provision as a critical factor for

\footnotetext{
121 Symeonides (2016).

122 Pitel \& Raferty (2016: 298-300).

123 See 'Question 1' above.

124 Competition and Consumer Act 2010 (Cth)- Schedule 2.

125 On the legislative history of ACL, see Corones (2016: 2-45).

126 Sections 3 (1) (b) \& s 23 (3), Competition and Consumer Act 2010 (Cth)- Schedule 2.

127 Ibid, Sects. 3 (1) (a) \& 23.

128 Ibid, Sects. 3 (1) (b) \& 23 (3).

129 Ibid, Sect. 23 (4). See also Clarke \& Elbacher (2018: 493-494).

130 Clough Engineering Ltd v Oil Natural Gas Corporation (2008) 249 ALR 458.

131 Sections 23-28, Competition and Consumer Act 2010 (Cth)- Schedule 2.

132 Ibid, Sects. 54-67.

133 Ibid, Sect. 23 (1).

134 Ibid, Sect. 27.

135 Ibid, Sects. 24- 25. See also Corones (2016: 209-249).
} 
determining whether a given contractual term is unfair. ${ }^{136}$ In this way, ACL significantly lowers the high bar of the common law unconscionability doctrine ${ }^{137}$ for challenging contractual terms on substantive grounds of unfairness. ${ }^{138}$

Sections 54-67 of ACL establish the "consumer guarantees" doctrine. It adds provisions into the contracts and provides an additional layer of contractual terms to protect the interests of the consumers. Thus, the mechanism of "consumer guarantees" incorporates statutory provisions that assure the quality of the products purchased by the consumer into the contract and that the product fits its stated purpose. ${ }^{139}$ ACL indicates that the parties cannot contract out the various consumer guarantees ${ }^{140}$ and it is up to the consumer to decide which remedy she or he should receive in case of a significant breach of one of the statutory guarantees. ${ }^{141}$ In contrast to the "unfair terms" mechanism, the principle of "consumer guarantees" does not apply to small businesses. In this way, ACL creates a sharp division between B2C contracts (as well as small businesses to which Australian consumer law applies on the point of the "unfair terms" doctrine) and Business to Business (B2B) modes of communication.

The factual basis of Valve Corporation involved a multibillion-dollar company called Valve which is based in the US state of Washington. It operates a global online distribution network through which customers purchase video games that they can play online and offline. Only a minority of the games have been developed by Valve itself. Valve has more than 2 million Australian subscriber accounts. The subscription agreement included a choice of law clause according to which the laws of the state of Washington, US, governed the subscriber agreement. ${ }^{142}$

The Federal Court of Australia decided that the choice of law clause is not valid based on contravening the mechanism of consumer guarantees under ACL. As this mechanism incorporates mandatory restrictions on the ability of the business to limit its refund policy, ${ }^{143}$ the application of the State of Washington law would have negated this regime. As the factual findings in Valve Corporation revealed, in several instances Valve refused to fully compensate its Australian customers when the downloaded video games did not work well. ${ }^{144}$ Valve relied on the specific terms and conditions in the subscription agreement, which said in capital letters: '...FEES ARE PAYABLE IN ADVANCE AND ARE NOT REFUNDABLE IN WHOLE OR PART'. ${ }^{145}$

\footnotetext{
136 ACCC v Chrisco Hampers Australia Pty Ltd [2015] FC 1204; ACCC v Richards \& Sons Pty Ltd [2017] FCA 1224; ACCC V Servcorp Ltd [2018] FCA 1044.

137 Commercial Bank of Australia Ltd v Amadio (1983) 151 CLR 447.

138 Paterson (2010).

139 Sections 54-55, Competition and Consumer Act 2010 (Cth)- Schedule 2.

140 Ibid, Sect. 64 (1).

141 Ibid, Sects. 259 (1) \& 260.

${ }^{142}$ For a description of the factual basis of the case, see Valve Corporation v ACCC [2017] FCAFC 224, paras. $1-41$.

${ }^{143}$ Section 64 (1), Competition and Consumer Act 2010 (Cth)- Schedule 2.

144 Valve Corporation v ACCC [2017] FCAFC 224, paras. 229- 334.

${ }^{145} \mathrm{Ibid}$, para. 2 (emphasis in original).
} 
Under the laws of the State of Washington, it is possible to limit the refund policy of the consumer. Under Australian law that would not be possible, as Valve breached ACL's consumer guarantee of acceptable quality (under ACL's Sect. 54) and was not eligible to limit the refund options in the provisions of the subscription agreements (under ACL's Sect. 64). ${ }^{146}$ This situation gave rise to fundamental question on whether ACL's consumer guarantees regime applies to the subscription agreement, in light of the parties' specific choice of the law of the State of Washington.

The Federal Court of Australia determined that ACL's regime of consumer guarantees applied and invalidated the abovementioned non-refund provision that would have been otherwise valid under US law. There are at least two ways to understand Valve Corporation. One way is to say that Valve Corporation has only partially invalidated the law of the State of Washington-that is the part where it contradicts the ACL's regime of consumer guarantees. ${ }^{147}$ The other option for understanding the decision is that Australian law would govern the other parts of the subscription agreement. One can argue that the entire choice of law clause should be invalidated as constituting an "unfair term" under the $\mathrm{ACL}^{148}$, which would pre-empt any application of the State of Washington law in this case.

The effect of this decision concerning the parameters of party autonomy in the choice of law still needs to be determined. While one of the leading Australian textbooks has characterised the application of the mandatory rules to the area of conflict of laws as "controversial", ${ }^{149}$ Valve Corporation has opened the gate for an argument about a complete invalidation of the party autonomy doctrine in a large number of cases - the large number of contracts that fall under the broad definitions of consumer and small business contracts and perhaps with some further implications to online modes of contracting. It is the authors' view that despite the remarkable vagueness of Valve Corporation, the analysis of the case should have focused on the principal question: What are the extraterritorial scope of Australian consumer law and its relationship to the party autonomy doctrine? The degree of rejection of the party autonomy needs to be determined in the future. However, we would like to make several observations on this point.

First, by adopting the interpretation that the choice of foreign law should not override mandatory rules in Australia, Valve Corporation brings the country's jurisprudence very close to the European position. ${ }^{150}$ What is required is a comprehensive discussion of the nature of those rules and their unfortunate historical origin, ${ }^{151}$ and it will assess whether the incorporation of those rules is consistent with the internal structure of the Australian legal system and cultural heritage. Each legal

\footnotetext{
146 Ibid, paras. 44-50.

147 Mortesen et al (2019: 447) ("So the law expressly chosen by the parties would still be applied where it did not demand a result inconsistent with the consumer protection law").

148 Indeed, this seems to be the possibility raised by Professor Garnett. See Garnett (2017: 586-587).

149 Davies et al (2020: 465).

150 Article 9, Regulation (EC) No 593/2008 of the European Parliament and the Council on the Law Applicable to Contractual Obligations (2008).

151 Peari (2018: 205-219).
} 
system is balanced in its own way. It cannot merely incorporate doctrines and concepts without observing their nature as a whole.

Second, and related to the first point, the position according to which Australian law prevails over other laws may have implications on an international level and the role of Australia as a member of the international community. This community comprises a multiplicity of states which are construed as equal. Ordinarily, the legal rules of the members of this community do not delve into a quality assessment of the provisions of other states. Giving the Australian law a priority over other regimes may jeopardise this fundamental insight of international order and the basic principle of comity of international order. The impact of the European system of mandatory rules might be different from that of Australia. Relatedly, one can contemplate on the potential impact of mandatory rules on the possibility of Australians recognising and enforcing their decisions abroad. In the online setting, foreign companies and businesses rarely own assets in Australia. To receive compensation, consumers would need to submit a claim for recognition and enforcement of the Australian court's decision in a foreign court. This is naturally the place where the foreign company owns assets so that the litigation will become an academic exercise. How would Valve Corporation affect the ability of Australians to recognise the Australian courts' decisions abroad?

Third, it could be argued that Valve Corporation litigation has demonstrated that Australian consumer law urgently needs a definition of an Australian consumer. The existing provision regarding the extraterritorial scope of Australian consumer law focuses on the product/service providers. It refers to such aspects of their activities as "carrying on business in Australia" and having "conducted business in Australia". ${ }^{152}$ While the scope of these provisions and its exact relevancy to the mandatory nature of the ACL needs to be further explored, ${ }^{153}$ its definitions are unfortunate. They seem to be meaningless in the context of online consumer interactions, where foreign companies sell products and services to Australian consumers. Online activity will always involve "carrying on business in Australia" and having "conducted" business in the country.

Moreover, online companies will rarely have assets in Australia. What is required is a focus on Australian consumers and a clear definition of the Australian consumer, which the law aims to protect. Does Australian consumer law seek to protect only permanent residents of Australia or also temporary residents, occasional workers, student visa holders and the like? Australia could have learnt from European Rome I Regulation ${ }^{154}$ which accepts the party autonomy doctrine in consumer contracts, unless the chosen law makes the consumer worse off. If the foreign law selected provides the consumer with more protection than the law of her or his

\footnotetext{
152 Valve Corporation v ACCC [2017] FCAFC 224, paras. 158- 206.

153 Two unexplained assumptions between the litigating parties in Valve Corporation created the uncertainty about the extraterritorial scope of the ACL: (1) the assumption to focus on mechanism of consumer guarantees as a starting point of judicial analysis (para 44); (2) the assumption that Sect. 131 of Australian Competition and Consumer Act 2010 (Cth) is relevant to litigation (paras 51, 158).

154 Article 6 (2), Regulation (EC) No 593/2008 of the European Parliament and the Council on the Law Applicable to Contractual Obligations (2008).
} 
habitual residence, the chosen law governs the contract. In this way, Rome I Regulation focuses on the place of consumers' habitual residence. ${ }^{155}$

Finally, the mandatory nature of Valve Corporation litigation should be reconciled with other types of consumer-driven contracts, such as insurance contracts discussed in Akai. In Akai, the High Court of Australia determined that the Sect. 8(2) of the Insurance Act Contract Act ${ }^{156}$ is of a mandatory nature, ${ }^{157}$ and will exclude the application of the party autonomy doctrine in insurance contracts. ${ }^{158}$ The relationship between conflict of laws rules applicable to insurance contracts and consumer contracts needs to be clarified, especially in the online context, which represents the predominant mode of contracting for both insurance and consumer contracts.

\section{Concluding Remarks}

In this paper, we have considered the Australian jurisprudence on the status and future of a crucial doctrine for international commerce: the party autonomy. Given the growing significance of this doctrine in ordinary forms of contracting and the escalating number of online dealings, tackling the validity of this doctrine, its scope and limitations could not be more critical.

We have considered what appears to be the critical aspects of the operational mechanics of the doctrine. Thus, for example, we have expressed support for incorporating a non-State choice of law clauses into Australian jurisprudence and have opted for a unifying framework of choice of law rules to govern all aspect of contract law. We have objected to the need to demonstrate a "meaningful" connection to the applied law, have challenged the application of the classical definition of the field as it applies to party autonomy and have disapproved of the potential integration of the doctrine of renvoi into choice of law rules of contract in Australia.

We designated special attention to the question of the relation between the party autonomy doctrine and the notion of mandatory rules. Valve Corporation has created a significant gap between B2B contracts (to which party autonomy applies) and B2C contracts (to which it is not clear, after Valve Corporation, to what extent the party autonomy doctrine applies). This gap needs to be adequately bridged, especially in light of the growing reality of online contracting. A standard set of underlying rationales drives $\mathrm{B} 2 \mathrm{~B}$ and $\mathrm{B} 2 \mathrm{C}$ (as well as small business contracts). These rationales support adopting predictable and reasonable choice of law rules in which the dominant party cannot abuse the rights of the weaker party.

\footnotetext{
155 Ibid. The place of the consumer's habitual residence appears to also be central under $\S \S 189 \& 197$ of the US Restatement (Second) of Conflict of Laws (1988) which says that contract should be governed by the place of performance. Since the delivery of goods usually takes place at the residence, this place becomes central under US law.

156 Section 8 (2), Insurance Contracts Act (1984) Cth. See also Akai Pty Ltd v People's Insurance Co Ltd (1996) 188 CLR 418, 431-432.

157 Davies et al (2020: 485) (points to the fact that in Akai, the court considered the operation of the Insurance Contracts Act as "essentially" a "mandatory rule").

158 Ibid, 489.
} 
Above all, the post Valve Corporation era requires a comprehensive approach to the question of the relation between the party autonomy doctrine and the mandatory rules. This approach would need to take the Australian system as a whole into account, including the specific nature of online transactions, B2B and B2C contracts, the nature of the party autonomy doctrine, the substantive doctrines of private international law, the concerns of businesses and the potential impact of the mandatory rules on the various aspects of commercial activity, especially during the unprecedented COVID-19 pandemic.

Acknowledgements The authors would to thank the participants of the Consumer Law Workshop and the Annual Contract Law Conference in Melbourne Law School for their constructive points. Also, the authors are grateful to Professors Justin Malbon (Griffith Law School) and Luke Nottage (Sydney Law School) for their helpful comments on this article.

Author contributions SP and SK has equally contributed to this work.

Funding The co-author, Saloni Khanderia has received funding from theAlexander von Humboldt Stipendium.

\section{References}

Anthimos, Apostolos. 15 April 2020 . Covid-19 and overriding mandatory provisions. online: conflictoflaws.net

Basedow, Juergen. 2013. The law of open societies-private ordering and public regulation of international relations. Recueil Des Cours 2012: 9.

Benoliel, Uri, and Shmuel I. Becher. 2019. The duty to read the unreadable. Boston University Law Review 60: 2255.

Boele-Woelki, Katharina. 2010. Unifying and harmonizing substantive law and the role of conflict of laws. Recueil Des Cours 2009: 275.

Borchers, Patrick J. 2008. Categorical exceptions to party autonomy in private international law. Tulane Law Review 82: 1645.

Briggs, Adrian. 1990. The Formation of International Contacts Lloyd's Maritime and Commercial Law Quarterly 1990: 192.

Briggs, Adrian. 2008. Agreements on jurisdiction and choice of law. Oxford: Oxford University Press. Briggs, Adrian. 2014. Private international law in English Courts. Oxford: Oxford University Press.

Briggs, Adrian. 2019. Conflict of laws, 4th ed. Oxford: Oxford University Press.

Clarke, P.H., and Sharon Elbacher. 2018. Australian consumer law. Lawbook Co: Thompson Reuters.

Corones, S.G. 2016. The Australian consumer law, 3d ed. Law Book: Thompson Reuters.

Coyle, John F. 2020. A short history of the choice-of-law clause. University of Colorado Law Review 91: 1147.

Davies, M., et al. 2020. Nygh's conflict of laws in Australia, 9th ed. Chatswood: LexisNexis Butterworths.

Fawcett, James, and J.M. Carruthers, eds. 2017. Cheshire, North \& Fawcett: Private international law, 15th ed. Oxford: Oxford University Press.

Garnett, Richard. 2017. Arbitration of cross-border consumer transitions in Australia: A way forward. Sydney Law Review 39: 569.

Geva, Benjamin, and Sagi Peari. 2021. International negotiable instruments. Oxford: Oxford University Press.

Graziano, Thomas Kadner. 2013. Solving the riddle of conflicting choice of law clauses in battle of forms situations: The hague solution. Yearbook of Private International Law 14: 71.

Graziano, Thomas Kadner. 2017. The hague solution on choice-of-law clauses in conflicting standard terms: Paving the way to more legal certainty in international commercial transactions? Uniform Law Review 22: 351.

Hayward, Benjamin. 2017. Conflict of laws and arbitral discretion. Oxford: Oxford University Press.

Hill, Jonathan, and Máire Ní. Shúilleabháin, eds. 2016. Clarkson \& hill's conflict of laws, 5th ed. Oxford: Oxford University Press. 
Khanderia, Saloni. 2018. indian private international law vis-à-vis party autonomy in the choice of law. Oxford University Commonwealth Law Journal 18: 1.

Khanderia, Saloni. 2019. International approaches as plausible solutions to resolve the battle of forms under the Indian law of contract. Global Journal of Comparative Law 8: 1.

Khanderia, Saloni (forthcoming 2021). The Ascertainment of the Applicable Law in the Absence of Choice in India and South Africa. Oxford University Commonwealth Law Journal

Kincaid, Peter. 1993. Rationalising contract choice of law rules. Ottago Law Review 8: 93.

Knop, Karen, et al. 2012. From multiculturalism to technique: Feminism, culture, and the conflict of laws style. Stanford Law Review 64: 589.

Kotuby, Charles T., and Luke A. Sobota. 2017. General principles of law and international due process. New York: Oxford University Press.

Lorenzen, Ernest G. 1917. Rules of the conflict of laws applicable to bills and notes. Minnesota Law Review 1917: 10.

Michaels, Ralf. 2008. Public and private international law: German views on global issues. Journal of Private International Law 4: 121.

Michaels, Ralf. 2014. Non-state law in the hague principles in the choice of law in international commercial contracts. In Varieties of European economic law and regulation: Liber amicorum for hans micklitz, ed. Kai Purnhagen and Peter Rot. Cham: Springer.

Mills, Alex. 2018. Party Autonomy in Private International Law. Cambridge: Cambridge University Press, 2018.

Mortesen, R., et al. 2019. Private international law in Australia, 4th ed. Chatswood NSW: LexisNexis Butterworths.

Neels, Jan L. 2015. The nature, objective and purposes of the hague principles on choice of law in international commercial contracts. Journal of South African Law 4: 774.

Nygh, P.E. 1999. Autonomy in international contracts. Oxford: Clarendon Press.

Pannebakker, Ekaterina. 17 April 2020. Force majeure certificates' issued by the Russian Chamber of Commerce and Industry. Online: conflictoflaws.net.

Paterson, J.M. 2010. The Australian unfair contract terms law: The rise of substantive unfairness as a ground for review of standard form consumer contracts. Melbourne University Law Review 33: 934.

Peari, S. 2018. The foundation of choice-of-law: Choice \& equality. New York: Oxford University Press.

Piovesani, Ennio. 9 March 2020. Italian Self-Proclaimed Overriding Mandatory Provisions to Fight Coronavirus. Online: conflictoflaws.net.

Pitel, S.G.A., and N.S. Rafferty. 2016. Conflict of Laws, 2nd ed. Toronto: Irwin Law.

Rühl, Giesela. 2003. The battle of forms: Comparative and economic observations. University of Pennsylvania Law Review 2003: 189.

Rühl, Giesela. 2014. The protection of weaker parties in the private international law of the European union: A portrait of inconsistency and truancy. Journal of Private International Law 18: 335.

Rühl, Giesela. 2018. The unfairness of choice-of-law clauses. Common Market Law Review 5: 201.

Svantesson, D.J.B. 2016. Private international law and the internet, 3rd ed. Wolters Kluwer: Kluwer Law International.

Symeonides, S.C. 2010. Party autonomy in Rome I and II from a comparative perspective. In Convergence and divergence in private international law, ed. Katharina Boele-Woelki, et al. Schulthess: Eleven International Publishing.

Symeonides, S.C. 2016. The choice-of-law revolution fifty years after currie: An end and a beginning. University of Illinois Law Review 2015: 1847.

Symeonides, Symeon C 2019 The Scope and Limits of Party Autonomy in International Contracts: A Comparative Analysis in Franco Ferrari \& Diego P Fernández Arroyo eds, Private International law: Contemporary Challenges and the Continuing Relevance of Private International Law and New Challenges. Elgar Publishing, Cheltenham

Tang, Sophia (1 March 2020). Coronavirus, force majeure certificate and private international law. Online: conflictoflaws.net.

Turner, Clive, et al. 2019. Concise Australian commercial law, 5th ed. Chatswood NSW: LexisNexis Butterworths.

van Bochove, L.M. 2014. Overriding mandatory rules as a vehicle for weaker party protection in European international law. Erasmus Law Review 3: 147.

Wang, Fangfei. 2019. Internet jurisdiction and choice of law. Cambridge: Cambridge University Press. 
Zhang, Mo. 2015. Rethinking contractual choice of law: An analysis of relation syndrome. Stetson Law Review 44: 831.

\section{Cases}

ACCC v Chrisco Hampers Australia Pty Ltd [2015] FC 1204.

ACCC v Richards \& Sons Pty Ltd [2017] FCA 1224.

ACCC V Servcorp Ltd [2018] FCA 1044.

Akai Pty Ltd v People's Insurance Co Ltd (1996) 188 CLR 418.

Amin Rasheed Shipping Corporation v Kuwait Insurance Co [1984] AC 50.

Clough Engineering Ltd v Oil Natural Gas Corporation (2008) 249 ALR 458.

Commercial Bank of Australia Ltd v Amadio (1983) 151 CLR 447.

Creutzburg v Commercial Bank of Namibia Ltd, [2006] 4 All SA 327.

Engel $v$ Adelaide Hebrew Congregation Inc (2007) 98 SASR 402

Enka Insaat ve Sanayi AS v OOO "Insurance Company Chubb [2020] 1 WLR 4117.

Gonzalez v Agoda Pty Ltd (2017) NSWSC 1133.

Halpern v Halpern [2007] EWCA Civ 291, [2007] 2 Lloyd's Rep 56.

Huntingdale Village Ltd v Corrs Chambers Westgarth (2018) 128 ACSR 168.

Kay's Leasing Corp v Fletcher (1964) 64 SR (NSW) 195.

Kumarina Investment Ltd. v Digital Media Convergence Ltd \& Anr, 2010 TDSAT 73.

National Thermal Power Corporation v Singer Corporation, 1992 (3) SCC 551.

Neilson v Overseas Projects (2005) 223 CLR 331; [2005] HCA 54.

Pfeiffer Pty Limited v Rogerson (2000) 203 CLR 503.

Proactive Building Solutions v Keck [2013] NSWSC 1500.

Queensland Estates Pty Ltd v Collas [1971] Qd R 75.

Representative of Lloyds v Classic Sailing Adventures (Pty) Ltd, 2010 (5) SA 90 (SCA).

Re South Head \& District Synagogue (Sydney) (2017) NSWSC 823.

Ship 'Sam Hawk' v Reiter Petroleum Inc (2016) 246 FCR 337.

Valve Corporation v ACCC [2017] FCAFC 224.

Vita Food Products v Unus Shipping Co [1939] AC 277

\section{Legal Acts}

Acts of Legislative Content of 13 April 2020

Australian Competition and Consumer Act 2010 (Cth).

Civil Code of the Russian Federation, 2015

Hague Principles on Choice of Law in International Commercial Contracts, 2015.

Inter-American Convention on the Law Applicable to International Contracts, signed at Mexico, March 17,1994

Insurance Contracts Act (1984) Cth.

Italian Civil Code

Japanese Act on the General Rules on the Application of Laws, 2007.

Principles of European Contract Law (Kluwer International Law, 1999) (PECL 1999)

Regulation (EC) No 593/2008 of the European Parliament and the Council on the Law Applicable to Contractual Obligations, 200

Restatement (Second) of Conflict of Laws (1988).

The Law of the People's Republic of China on the Laws Applicable to Foreign-Related Civil Relations, 2010.

Turkish Code on Private International Law and International Civil Procedure, 2007

UNIDROIT, UNIDROIT Principles on International Commercial Contracts, 2016

Publisher's Note Springer Nature remains neutral with regard to jurisdictional claims in published maps and institutional affiliations. 